\author{
돼지난소에서 난포폐쇄시 과립층세포의 아포토시스와 \\ 대식세포에 관한 형태학적 연구 \\ 박창식* . 한승로** . 김수일** . 조근자** . 김원식** \\ 충남대학교 형질전환복제돼지연구센터*, 충남대학교 의과대학**
}

\title{
A Morphological Study on the Granulosa Cell Apoptosis and Macrophages during Follicular Atresia in Pig Ovary
}

\author{
C. S. Park*, S. R. Han**, S. I. Kim**, K. J. Cho** and W. S. Kim** \\ Division of Animal Science \& Resources, Research Center for Transgenic Cloned Pigs, \\ Chungnam National University*, \\ College of Medicine, Chungnam National University**
}

\begin{abstract}
It is known widely that granulosa cell apoptosis leads follicular atresia and macrophages exert their effects directly and/or indirectly from the initiation to the completion of follicular atresia by phagocytosis of apoptotic bodies and secretion of various cytokines. However, the site of initiation, propagation routes and the elimination methods of apoptotic bodies, and the time and methods of penetration of macrophages into the follicles are not known completely. Using pig(Yorkshire-breed) ovary, immunohistochemical studies with TUNEL for apoptotic bodies and pig macrophage monoclonal antibody 4E9 for macrophages, and light and transmission electron microscopic observations were performed. In the pig, follicular atresia began with the granulosa cell apoptosis, and the apoptosis of theca interna cells occured at the same time. The apoptosis of granulosa cells initiated randomly within the granulosa cell layer and propagated rapidly into the whole layer. Ultrastructurally, apoptotic granulosa cells showed characteristic pyknotic and deformed nucleus and intracytoplasmic vesicles. Apoptotic bodies were eliminated by intact granulosa cells and macrophages. Intact granulosa cells ingested apoptotic bodies transiently, soon after they fell into the apoptosis. Finally, apoptotic bodies and degenerated oocyte were phagocytosed by macrophages. Macrophages entered the ovarian follicle at the time of initiation of granulosa cell apoptosis, and migrated with the progression of apoptosis. By elimination of theca cells, macrophages contributed the completion of follicular atresia. These results will provide valuable informations on the study of the interrelation between macrophage and ovarian follicular atresia.
\end{abstract}

(Key words : Follicular atresia, Granulosa cell, Apoptosis, TUNEL, Macrophage, Immunohistochemistry)

$\begin{array}{cl}\text { I 서 론 } & \text { Takashita 등, 1995), 변태에서(Lockshin and } \\ & \text { Zakeri, 1991) 그리고 종양퇴축을 포함한 여러 } \\ \text { 아포토시스(apoptosis)는 일반적으로 여러 조 } & \text { 종류의 조직질환에서(Cope와 Willie, 1991), 허 } \\ \text { 직내에서(Wyllie 등, 1973a, b; Hun 등, 1993; } & \text { 혈증에서(Nitatori 등, 1995; Ikeda 등, 1995), 신 } \\ \text { Iwanaga 등, 1993; Nakamura 등, 1995; Shibahara } & \text { 경질환에서(Clarke, 1991; Lo 등, 1995), 독소에 } \\ \text { 등, 1995), 배아발생에서(Tanigucci 등, 1995; } & \text { 노출시(O'Shea 등, 1978; Suzuki 등, 1995) 및 조 }\end{array}$

Corresponding author : W. S. Kim, College of Medicine, Chungnam National University, Daejeon 301-131, Korea. Tel : 042-580-8202, E-mail : wonsikk@cnu.ac.kr 
직위축시(Abe와 Watanabe, 1995) 적정한 세포의 수를 유지하기 위해 일어나며, 이 아포토시스 의 조절 과정이 정상적으로 이루어지지 못하면 종양, 자가면역질환, 후천성 면역결핍증 및 선 천성 기형 등이 발생되는 것으로 알려져 있다 (Singh과 Anand, 1995). 이 아포토시스는, 일반 적인 괴사와는 달리 세포의 위축, 염색질 농축 및 DNA 절편화가 특징적으로 나타나며 아포토 시스가 진행된 세포와 아포토시스 소체(apoptotic body)는 여러 개의 작은 조각들로 나누어 져 탐식되어 진다(Schulte-Hermann 등, 1992; Ueda와 Shah, 1994; Singh과 Anand, 1995).

포유동물에서 난포는 성숙하여 배란에 이르도 록 예정되어 있는 일부(1\% 미만)를 제외하고는 대부분(99\% 이상) 폐쇄의 과정을 걷게 된다(Arai, 1920). 난포폐쇄와 관련되어 다수의 형태학적 변 화(Hirshfield와 Midgley, 1978; O'Shea 등, 1978; Tsafriri와 Braw, 1984)와 기능적 변화(Uilenbroek 등, 1980; Terranova, 1981)에 관한 연구들이 행해 져 왔으며, 최근까지의 연구에서 난포폐쇄가 난 포 과립층세포들과 난모세포에서 유전적으로 계 획된 세포사망인 아포토시스에 의해 일어나는 것으로 밝혀져 있다(Tilly 등, 1991; Hughes와 Gorospe, 1991). 과립층세포에서 나타나는 아포토 시스도 일반세포들에서와 마찬가지로 핵에서는 염색질농축(Gougeon, 1996)이 일어나고 세포질에 서는 세포질 수축이 일어나고 이들은 종종 작은 막성 조각들로 나뉘어져(Uchiyama, 1995) 많은 아포토시스 소체를 형성한다. 따라서 아포토시스 의 진행은 아포토시스 소체들을 관찰하므로서 그 정도를 알 수 있을 것이다. 아포토시스 소체 는 통상적으로 행하는 $\mathrm{H} \& \mathrm{E}$ (hematoxylin and eosin) 염색을 통해서도 일부 관찰되고 toluidine blue 염색을 통해서도 관찰되나 최근 특이성이 높은 TUNEL 방법이 자주 이용되고 있다.

한편, 아포토시스에 의해 사망한 과립층세포들 은 자가용해에 의해 사라지거나(Logothetopoulos 등, 1995), 인접한 정상 과립층세포에 의해 탐 식(Kuryszko와 Adamski, 1987; Koike 등, 1993; Takeo와 Hokano, 1995; Watanabe와 Tonosaki, 1995)되는 것으로 알려져 왔으나, 일부 대식세포 가 관여하고 있음이 마우스(Kuryszko와 Adamski,
1987; Inoue 등, 2000), 랫드(Bukovsky 등, 1993), 기니픽(Kasuya, 1997), 토끼(Kasuya, 1995) 및 사 람(Bukovsky 등, 1995)을 대상으로 한 실험에서 밝혀졌다. 난포폐쇄에서 아포토시스 소체들의 제거는 필수적인 과정이나 제거방식에 대해서 는 이렇듯 아직 논란의 여지가 있음은 문제점 으로 생각된다. 그런데, 이 대식세포가 난포내 에서 죽은 또는 죽어가는 과립층세포들을 제거 하여 난포폐쇄에만 관여하는 것이 아니고, 최 근의 연구에서는 대식세포가 랫드에서 과립층 세포의 증식에 관여하고(Fukumatsu 등, 1992) 생쥐(Kirsch 등, 1981)와 사람(Halme 등, 1985)에 서 배양중인 난포세포에서 프로제스테론(progesterone)의 생산을 촉진하고, FGF(fibroblast growth factor)와 EGF(epidermal growth factor) 등 각종 cytokines을 분비하여 난소의 기능을 조절하고(Katabuchi 등, 1996), 황체형성과 황체 용해 등과 관련(Pate와 Keyes, 2001)되는 등이 알려지면서, 난포내 대식세포에 관한 연구가 활발히 진행되고 있다. 그러나 아직 난포내에 서 난포의 성장 및 폐쇄과정에서 대식세포의 위치, 형태, 출현시기 등에 대한 구체적인 연구 가 행해져 있지 않아 대식세포가 갖고있는 다 양한 기능을 추정하기에 어려움이 많다.

나아가 지금까지의 연구는 대부분 랫드, 마 우스, 토끼 등을 대상으로 한 것들이고 돼지를 대상으로 한 연구는 매우 드물다(Berndt 등, 2000; Domenech 등, 2003). 이는 돼지가 실험동 물로서 사육, 취급 등의 어려움과 경제성이 떨 어지는데 그 원인이 있을 것으로 보이나, 돼지 는 가축으로서의 중요성 외에도 이식 또는 동 맥경화증과 같은 생물의학적 연구분야에서 유 용한 동물모델로 널리 사용되고 있고 최근에는 생명공학의 발전으로 대체기관의 생산이나 형 질전환을 통한 이식조직의 생산 또는 복제 등 에 활용되고 있어 돼지에 관한 연구는 매우 중 요한 의미가 있을 것이다.

이에 저자들은 돼지 난소에서 난포 과립층세 포의 아포토시스 소체와 이들을 포식하는 대식 세포를 면역조직화학적 방법과 투과전자현미경 적 방법으로 관찰하여 난포폐쇄중 이들의 관계 를 알아보기 위해 본 연구를 실시하게 되었다. 


\section{ㅍ 실험재료 및 방법}

\section{1. 실험동물}

본 실험에 사용한 실험동물은 생후 $8 \sim 10$ 개 월의 가임기 암컷 돼지(Yorkshire-breed swine)로 서, 충남대학교 형질전환복제돼지연구센타에서 실험에 사용하는 정상 돼지 20마리의 난소를 직접 공급받아 사용하였다. 적출한 난소는 적 절히 절단하여 $\mathrm{H \& E}$ 염색을 실시할 조직과 면 역조직화학적 연구를 실시할 조직은 $10 \%$ 중성 포르말린용액(buffered neutral formalin sol.)에 고정하고, 투과전자현미경 관찰을 위한 조직은 $0.1 \mathrm{M}$ phosphate buffer saline으로 $2.5 \%$ glutaraldehyde 용액 $(\mathrm{pH} \quad 7.4)$ 을 만들어 $4^{\circ} \mathrm{C}$ 에서 전 고정하였다.

\section{2. 광학현미경적 방법}

돼지 난소의 일반적인 조직학적 구조를 광학 현미경적으로 관찰하기 위해 적출한 난소를 $10 \%$ 중성포르말린용액에 24시간 고정한 후, 통 상적인 방법에 따라 파라핀(paraffin) 포매하고 $5 \mu \mathrm{m}$ 두께로 박절하여 $\mathrm{H} \& \mathrm{E}$ 염색 표본을 제 작하였다.

\section{3. 면역조직화학적 방법}

\section{(1) 아포토시스 소체의 면역염색}

난포의 퇴축이 진행되면서 나타나는 난포 과 립세포의 아포토시스의 정도를 면역조직화학적 으로 관찰하기 위해 절편화된 DNA를 염색할 수 있는 TUNEL(TdT-mediated dUTP biotin nick end labelling) 염색을 실시하였다. 우선 $5 \mu \mathrm{m}$ 두께로 박절한 조직절편을 silanized coating slide(DAKO Corporation, USA) 위에 부착시켜 슬라이드를 제 작하고 탈파라핀 후 ApopTag Kit(Intergen Co., $\mathrm{USA}$ )를 사용하여 실시하였다. 파라핀이 제거된 조직절편을 0.05M PBS(phosphate buffered saline, $\mathrm{pH}$ 7.4) 용액으로 5 분간 수세한 다음 proteinase $\mathrm{K}(20 \mathrm{\mu g} / \mathrm{ml}$ in $0.05 \mathrm{M} \mathrm{PBS})$ 로 실온에서 $25 \sim 30$ 분간 반응시킨 후 증류수로 2 분간 3 회 수세하여
핵산을 둘러싸고 있는 단백질을 제거하였다. 또 한 내재성 peroxidase의 활성 제거를 위해 $2 \%$ $\mathrm{H}_{2} \mathrm{O}_{2}$ 액에 30 분간 반응시킨 다음 $0.05 \mathrm{M}$ PBS 용 액으로 5 분간 2회 세척하고 equilibration buffer에 10 분간 반응시켜 주변부에서 일어날 수 있는 비 특이적 반응을 억제하였다. 이후 reaction buffer $77 \mu \ell$ 와 terminal deoxynucleotidyl transferase(TdT) $33 \mu l$ 를 혼합하여 working strength $\mathrm{TdT}(108$ $\mu$ l/slide)를 만든 후, 조직절편에 떨어뜨린 다음 커버글라스(coverglass)를 덮고 $37^{\circ} \mathrm{C}$ humidified chamber에서 1 시간 동안 반응시켰다. 이들 조직 은 $37^{\circ} \mathrm{C}$ 의 working strength stop/wash buffer에 10 분간 실온에서 반응시켰다. 이후 $0.05 \mathrm{M}$ PBS용 액으로 5분간 3회 세척하고 anti-digoxigeninperoxidase를 실온의 humidified chamber에서 5시 간 동안 반응시켰다. 반응이 끝난 조직절편은 0.05M PBS용액으로 5분간 3회 세척 후 $0.05 \%$ diaminobenzidine(DAB)에 $0.3 \% \mathrm{H}_{2} \mathrm{O}_{2}$ 를 첨가하여 20 분간 실온에서 발색시켰으며 $0.1 \mathrm{M}$ sodium acetate buffer solution으로 $0.5 \%$ methylgreen $(\mathrm{pH}$ 4.0)을 만들어 10 분간 실온에서 대조염색을 하였 다. 염색이 끝난 조직절편은 수세 후 $100 \%$ ethanol로 탈수하고 xylene 처리한 다음 Permanent mounting media(DAKO Corporation, USA)로 봉입하였다.

\section{(2) 대식세포의 면역염색}

돼지 난포내 대식세포의 면역조직화학적 염 색(Domenech 등, 2003)을 위해 신선한 난소조 직을 먼저 $10 \%$ 중성포르말린용액에 고정하고 파라핀 포매하였다. $5 \mu \mathrm{m}$ 두께로 박절한 조직 절편을 silanized coating slide(DAKO Corporation, USA) 위에 부착시켜 슬라이드를 제작하고 절 편을 xylene으로 탈파라핀 처리하고 $100 \%, 90 \%$, $80 \%, 70 \%$ 에탄올의 순서로 함수 후, $\mathrm{PBS}(\mathrm{pH}$ 7.6)로 두 차례 세척하고, $3 \%$ 과산화수소(DAKO Corporation, USA)를 20분 동안 endogenous peroxidase block 처리한 후 다시 PBS로 세 차 례 세척하였다. 다시 이 절편을 $0.01 \mathrm{M}$ sodium citrate buffer(pH 6.0)에 10분간 전자렌지에 끓이 고 30분간 식혔다. 절편을 Dominguez(Domenech 등, 2003)로부터 직접 공급받은 1 차 항체 $4 \mathrm{E} 9$ 
로 1시간 동안 처리하였다. PBS로 3분 3회 세 척후 biotinylated Link(DAKO Corporation, USA) 에 10 분간 처리하고, PBS로 3분 3회 세척후 다 시 Stretavidin-HRP(DAKO Corporation, USA)로 10 분간 처리하였다. 그리고 $\mathrm{PBS}$ 로 3 분 3 회 세 척후 $\mathrm{DAB}$ (diaminobenzidine tetrahydrochloride, DAKO Corporation, USA)를 이용하여 발색시킨 후, 절편을 세척하고 헤마톡실린으로 대조 염색 하여 광학현미경(Nikon, Japan)으로 관찰하였다.

\section{4. 투과전자현미경적 방법}

투과전자현미경적 관찰을 위하여 적출된 난 소의 한쪽을 $2.5 \%$ glutaraldehyde(pH 7.4) 용액에 $4{ }^{\circ} \mathrm{C}$ 에서 약 2 시간 정도 담가서 전고정한 후 $1 \mathrm{~mm}^{2}$ 의 크기로 세절하였다. 세절된 조직을 $0.1 \mathrm{M}$ phosphate buffer(pH 7.4)에 세척한 후 $0.1 \mathrm{M}$ phosphate buffer saline으로 $2 \%$ osmium tetroxide 용액 $(\mathrm{pH} 7.4)$ 을 만들어 $4{ }^{\circ} \mathrm{C}$ 에서 1 시간 동안 진탕하면서 후고정하였다. 고정된 조직은 $4{ }^{\circ} \mathrm{C}$ 의 $50 \%, 70 \%, 80 \%, 90 \%, 95 \%$ ethanol, 실온 의 $100 \%$ ethanol을 이용하여 점진적으로 탈수 하고 propylene oxide로 치환시켰다. 포매는 epon 812 혼합액을 사용하였고 경화제로는 dodecynyl succinic anhydride(DDSA)와 methyl nadic anhydride(MNA)를 사용하였는데 이때 가속제로 서는 2,4,6-dimethylamino-methyl phenol(DMP-30)을 사용하였다. 포매조작은 탈수와 치환이 끝난 후 propylene oxide와 epon 혼합액의 비가 1:1, $1: 2$, 그리고 순수 epon 혼합액에 각각 단계적으 로 침투시켰다. 이와 같은 조작이 끝난 후 시 료를 epon 혼합액에 포매하고 항온기에 넣어 $37^{\circ} \mathrm{C}$ 에서 12 시간, $45^{\circ} \mathrm{C}$ 에서 12 시간 그리고 $60^{\circ} \mathrm{C}$ 에서 48시간 동안 중합시켰다.

초박절편기(Sorvall ultramicrotome)를 사용하 여 $1 \mu \mathrm{m}$ 의 준초박절편(semithin section)을 제작 한 후 toluidine blue 염색을 하여 광학현미경으 로 확인한 다음, 적당한 부위를 택하여 60 $80 \mathrm{~nm}$ 두께의 초박절편(ultrathin section)을 만들 고 uranyle acetate와 lead citrate로 이중염색하여 투과전자현미경(Hitachii H600, Japan)으로 관찰 하였다.

\section{III 결과 및 고찰}

모든 성장중인 난포는 그것들이 일차난포, 이차난포 또는 커다란 난포동난포에 관계없이 모두 난포폐쇄를 일으키며, 아포토시스가 난포 폐쇄의 개시시간 또는 개시자극의 여부에 관계 없이 과립층세포의 죽음에 기본적인 기전을 제 공(Hughes와 Gorospe, 1991)한다고 알려져 있다. 따라서 본 실험에서 아포토시스 소체들을 관찰 하기 위해 그것들에 특이하게 반응하는 TUNEL 염색법을 택한 것은 합리적이며 결정적인 방법 이라고 생각한다. 따라서 TUNEL 음성인 난포 는 폐쇄가 개시되지 않은 상태이거나 배란을 일으킬 난포로 성숙되도록 선택되어진 것들이 며, 모든 난포 과립세포들이 가지고 있는 아포 토시스 프로그램이 아직 억제되어 있는 것으로 생각된다. 이와 관련지어 생각해 볼 때 배란시 까지 성숙되도록 선택된 난포의 과립층세포들 또는 난포막세포들은 배란 후까지 이 아포토시 스 능력을 갖고 있으며 결국 황체 용해시 이 프로그램이 활성화(Zeleznik 등, 1989)되어 황체 용해로 진행되는 것으로 보인다. 즉, 모든 난포 는 배란전에는 난포 폐쇄로 배란 후에는 황체 용해에 의해 사라지는 만큼, 난포의 운명에서 아포토시스에 의한 사망은 피할 수 없는 것으 로 생각된다(Hughes와 Gorospe, 1991).

이와 같이 과립층세포의 아포토시스는 난포폐 쇄를 일으키는 결정적인 기전(Hughes와 Gorospe, 1991; Tilly 등, 1991)이다. 지금까지, 과립층세 포의 아포토시스는 안쪽 층에서부터 개시되어 바닥막쪽으로 진행되고(Amsterdam 등, 1998) 이 어서 난자세포를 둘러싸고 있는 과립층세포들 까지 파급되는 것으로 알려져 있으나, 본 실험 에서는 H\&E 염색에서 아포토시스를 개시하는 것으로 보이는 농축핵을 가진 세포들이 과립층 내에서 일정하지 않게 분포하였고(Fig. 1) TUNEL 염색에서도 아포토시스 소체들이 일정치 않게 분포하였으며(Fig. 6), 투과전자현미경 관찰에서 도 기저막에 부착된 일부 과립층세포들이 다른 부위에 위치한 세포들보다 먼저 아포토시스를 일으키는 것이 발견되어(Fig. 16), 돼지 난포 과 립층에서 아포토시스는 층내의 위치와 관계없 

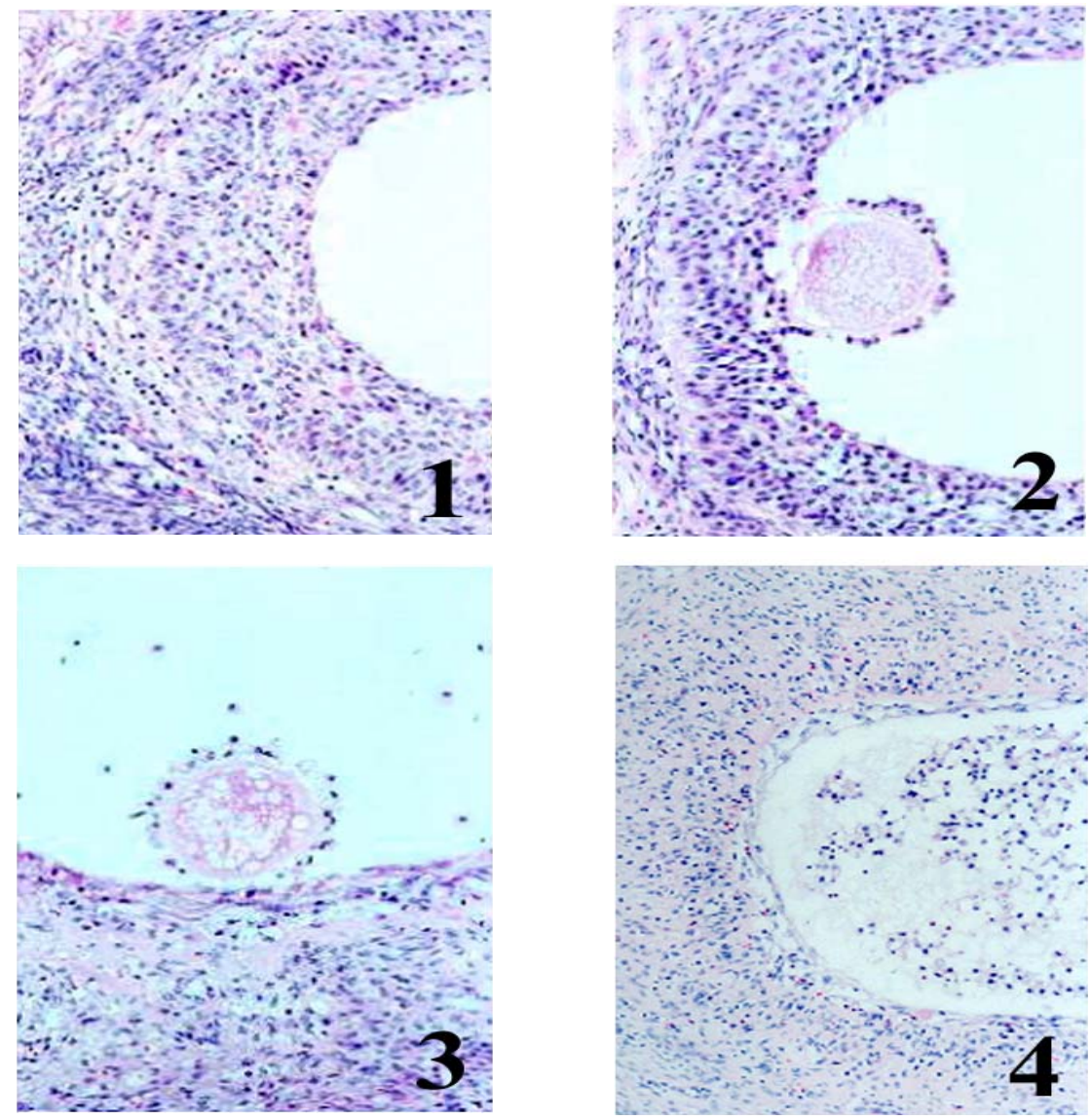

Fig. 1-4. Pyknotic granulosa cells in the granulosa layer and theca interna (1) and deformed zona pellucida (2) at early stage of atresia, pyknotic granulosa cells around degenerating oocyte, distintegrated basement membrane and stroma-transformed theca interna (3), and separation of pyknotic granulosa cells from the basement membrane (4) at advanced stage are observed. H \& E stain, X 100(1, 2, 4); X 200(3).

이 무작위적으로 개시되는 것임을 알 수 있었 다. 이렇게 개시된 아포토시스는 일정한 경로 를 거치지 않고 과립층 전체에 파급되고(Fig. 1, 6), 모두 아포토시스를 일으킨 과립층세포들은 바닥막으로부터 분리되어 난포동 내로 떨어져 나오게 되며(Fig. 4, 7, 8), 아포토시스의 진행과 함께 난모세포도 변형을 일으키면서(Fig. 2) 퇴 화단계로 들어갔고 최종적으로 난모세포 주위에 있는 과립층 세포들의 아포토시스(Fig. 3)가 뒤 따르는 것으로 관찰되어 난포 폐쇄시 아포토시 스의 파급과정을 밝힐 수 있었으며, 아울러 과 립층세포들의 아포토시스 진행과 함께 대식세포 들도 이동하는 것으로 관찰되었다(Fig. 9 12).
아포토시스의 정도를 검사할 수 있는 TUNEL 방법을 이용한 면역조직화학적 염색에서 일부 난포 폐쇄가 시작되지 않은 난포들은 TUNEL 반응에 음성을 나타냈으나(Fig. 5), 난포 폐쇄가 개시되었거나 진행중인 난포내에서 그 진행정 도에 따라 아포토시스를 일으킨 과립층세포들 과 그들로부터 생성된 아포토시스 소체들이 모 두 갈색의 양성반응을 보였다(Fig. 5 8). 그리 고 그 진행정도에 따라 과립층세포의 아포토시 스가 개시된지 얼마 되지 않는 난포에서는 TUNEL 양성반응 세포들이 과립층 속에서만 발견되었고(Fig. 6), 좀 더 진행된 난포에서는 과립층과 난포동 모두에서 관찰되었으며(Fig. 7) 

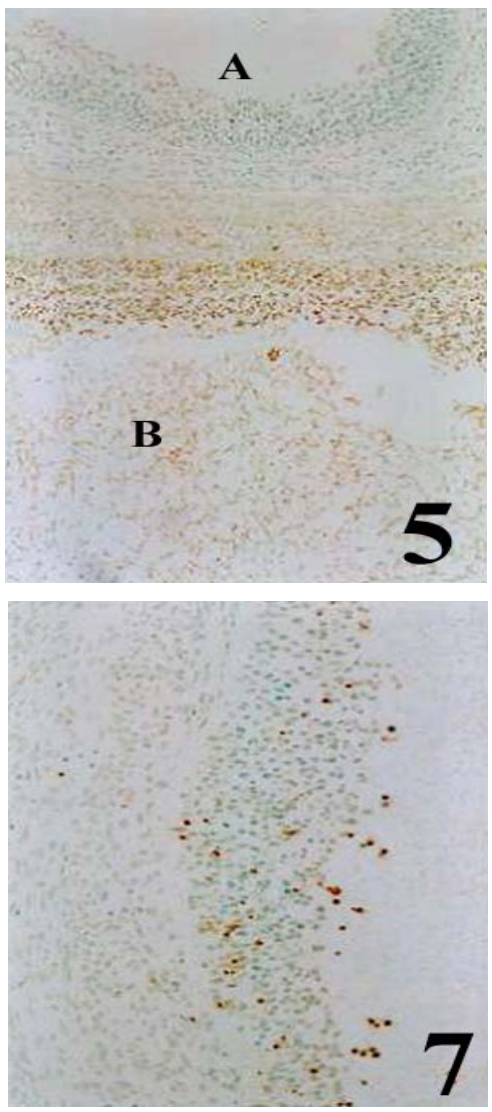
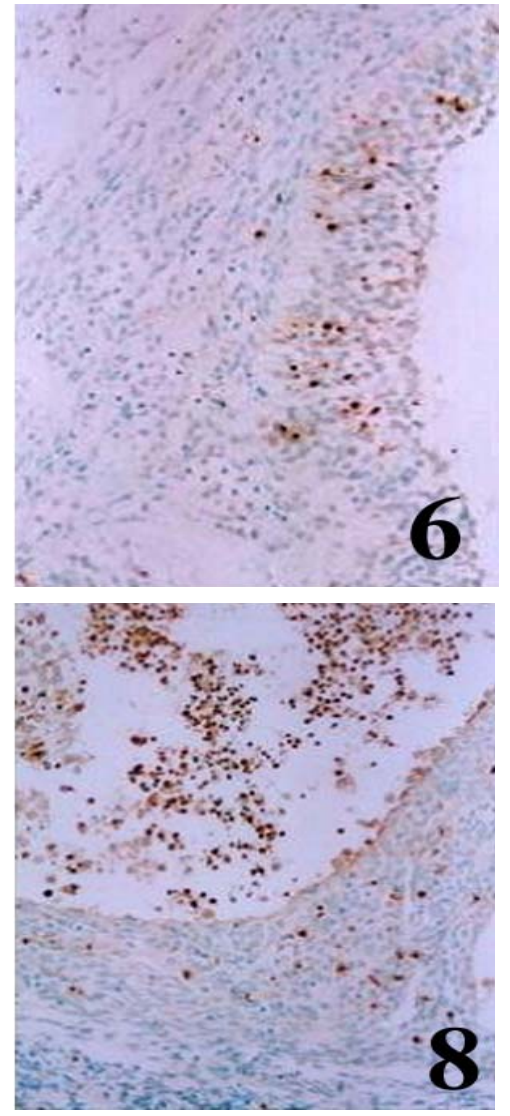

Fig. 5-8. TUNEL negative normal follicle (A) and positive atretic follicle (B) (5). Apoptotic bodies in the granulosa layer at eraly stage of atresia $(5,6)$, in the follicular antrum at midstage (7), and separation from the basement membrane at advanced stage (8) are observed. TUNEL immunostain, X 100(5); X 200(6, 7, 8).

더욱 진행된 난포에서는 과립층세포들이 모두 아포토시스를 일으켜 난포 기저막으로부터 난 포동내로 떨어져 나온 것들도 관찰되었는데 (Fig. 8), 이는 난포폐쇄중 과립세포층의 두께가 얇아지고 다수의 아포토시스 소체가 나타나며 난포동내에 세포조각들이 증가했다는 결과 $(\mathrm{Kim}$ 등, 1999)와 동일한 소견을 보였다. 특히 지금 까지는 난포막을 구성하고 있는 세포들의 아포 토시스는 난포 폐쇄가 완료될 시기에 일어난다 (Isobe와 Yoshimura, 2000; 김 등, 2002)고 알려 져 있으나, 본 실험에서는 과립층세포들에서 아포토시스가 개시되는 초기에 난포막 속층에서 도 TUNEL 양성 세포들이 발견되어(Fig. 5 8), 난포 폐쇄시 난포막의 와해는 난포속에서 일어 나는 아포토시스의 진행과 보조를 맞춰 진행되
는 별개의 과정으로 생각된다.

과립층세포에서 아포토시스를 일으키는 기전 은 명확히 알려져 있지 않다. 그러나, 다른 계 통에서 일어나는 아포토시스는, genomic DNA 를 oligonucleosomal fragments로 쪼개는 endonuclease의 활성화와 관련되며, 이 효소의 활성 화는 어떤 특징적인 형태변화가 일어나기 전에 일어나는 초기 비가역적 이벤트이며(Wyllie, 1980), 나아가, 이 효소에 의한 genome의 분절 은 이어지는 세포사망의 직접적인 원인이 되는 것(Wyllie, 1980; Compton과 Cidlowski, 1986)으 로서, 이와 같은 endonuclease 활성이 분화중인 과립층세포에서 이미 그 존재가 확인된 바 있 어(Zeleznik 등, 1989), endonuclease를 활성시키 는 물질 또는 환경에 의해 난포 폐쇄가 일어날 

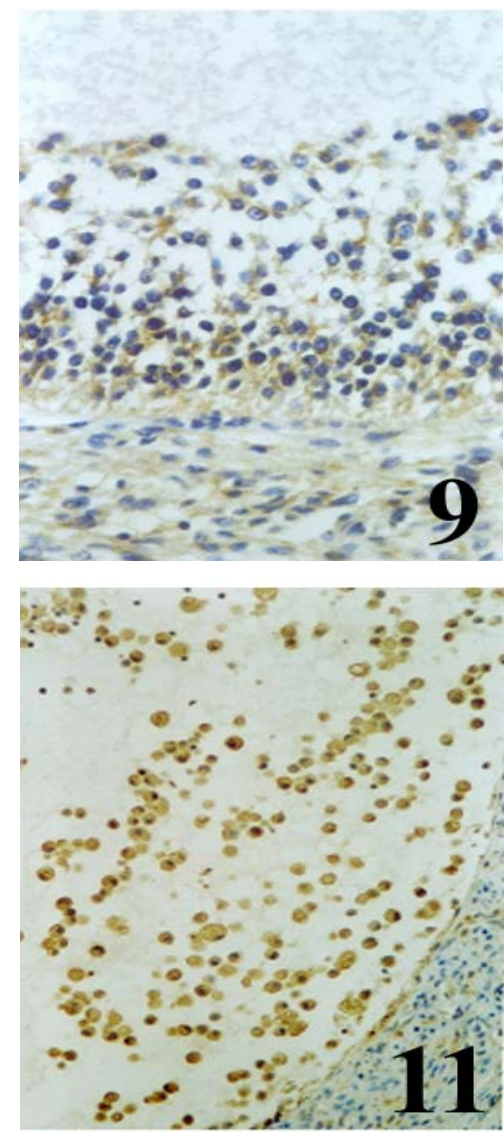
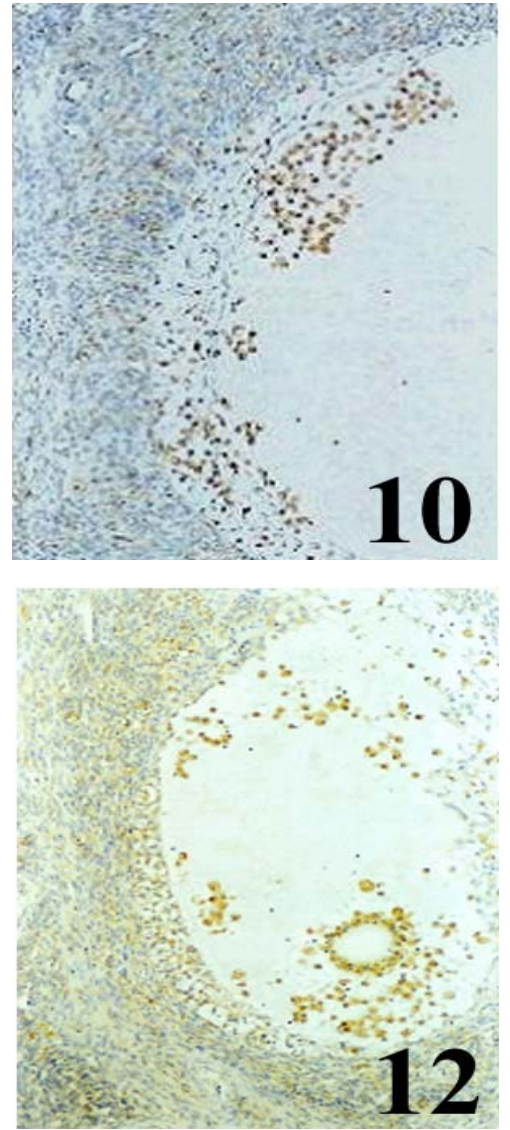

Fig. 9-12. 4E9 positive macrophages in granulosa layer in early stage (9), in granulosa layer, antrum and theca folliculi (10), in antrum (11), and around the zona pellucida (12) in advanced stage are observed. X 100(10, 12); X 200(11); X 400 (9).

것이다. 생체내에서 난포는 $\mathrm{FSH}$ 와 같은 gonadotropins와 $\mathrm{GF}$ (growth factor)인 FGF 등과 같은 주변분비물질 및 자가분비물질 등에 노출되며, 이것들이 단독으로 또는 복합적으로 과립층세 포들의 아포토시스를 유도하고 궁극적으로 난 포폐쇄를 개시하고 조절하므로써 우월난포의 선택에도 중요한 역할을 할 것으로 생각된다. 그러나, 그 물질이 무엇인가에 대해서는 앞으 로 좀더 연구해야 할 것이다.

투과전자현미경 소견에서 정상 과립층세포는 다각형이며 핵/세포질비가 비교적 큰 세포로 세포질내에는 과립세포질세망과 연결된 관구조 들이 밀집되어 있었고, 과립층세포들 사이는 교통반점에 의해 세포연결이 잘 유지되어 있었 다(Fig. 13). 일단 아포토시스가 개시된 과립층
세포에서는 세포형태가 변형되고 핵에서 특징 적인 염색질 농축과 분절형성, 톱니모양으로 들어간 핵의 윤곽, 염색질의 부분적인 농축 등 이 관찰되고, 세포질내에서는 사립체의 팽창, 과립세포질세망 능선의 팽창, 불규칙하고 전자 밀도가 높은 과립의 밀집, 지방방울의 축적, 다 양한 소포 형성, 용해소체의 증가 및 아포토 시스 소체 형성 등의 전형적인 아포토시스 소 견과 함께 인접한 정상과립세포들과 교통반점 을 가지고 있었다(Fig. 14, 15). 이는 일반세포 의 아포토시스시 일어나는 공통소견에 속하지 만, 세포질내에서 내향성 소포형성의 관찰은 그 기간이 너무 짧기 때문에 관찰하기 어렵다 (Kerr 등, 1987)는 보고를 고려할 때, 본 연구에 서 이것의 관찰은 의미있는 것으로 생각되며, 

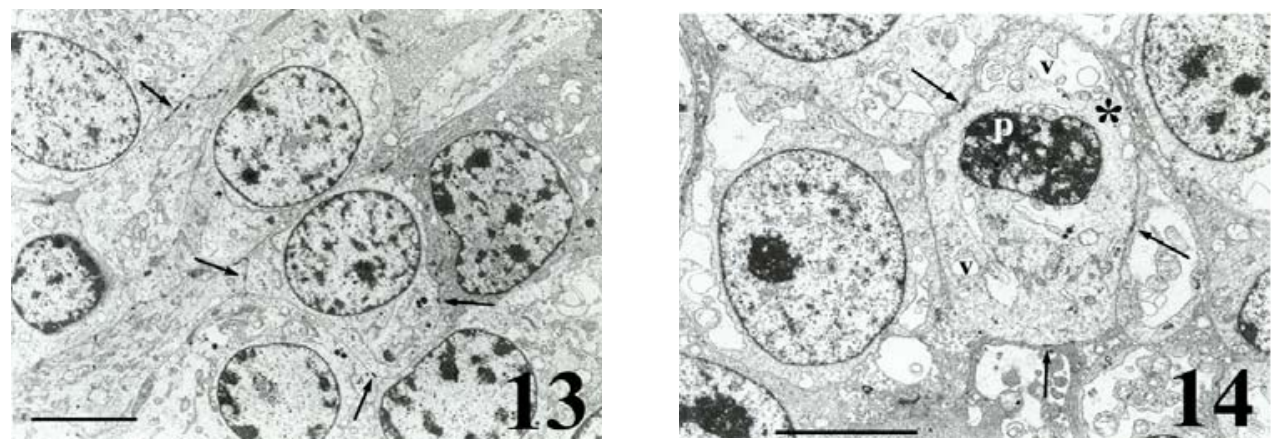

Fig. 13,14. Normal polygonal granulosa cells which have relatively high N/C ratio and gap junctions(arrow) with neighboring granulosa cells (13), and a granulosa cell undergoing apoptosis (asterisk) which have intracytoplasmic vesicles (v) and a pyknotic nucleus (p) are observed. bar $=5 \mu \mathrm{m}$.
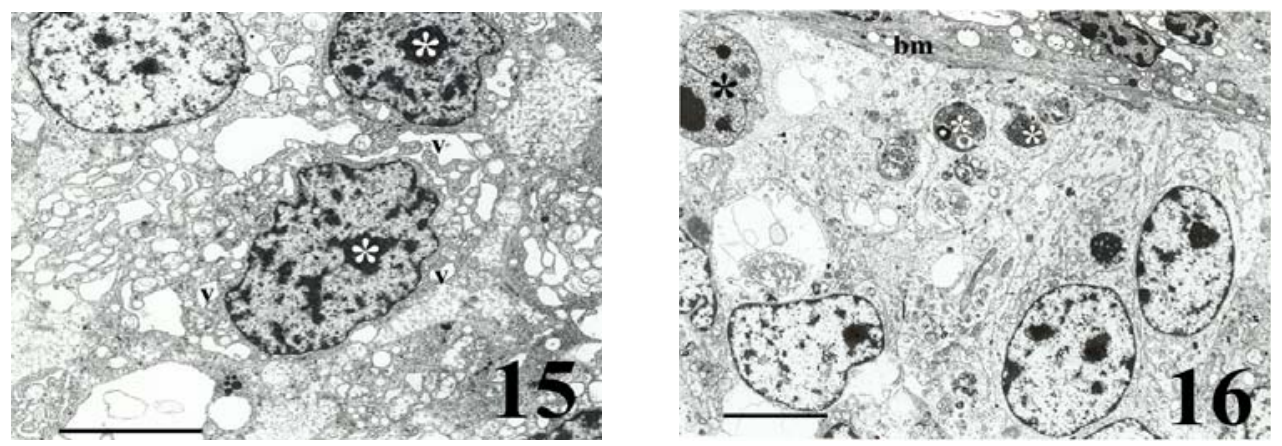

Fig. 15,16. Granulosa cells undergoing apoptosis(asterisk) which contain many well-developed intracytoplasmic vesicles(v), a prominent pyknotic nucleus( $p)$ having irregular nuclear membrane (15), and some apoptotic granulosa cells attached to the basement membrane (16) are observed. bar $=5 \mu \mathrm{m}$.

이러한 소포형성(Clarke, 1991) 동안에는 세포질 내 용해소체계통이 활성화되어 막성구조물들과 세포질의 일부분을 분해하여 자가포식공포를 형성하는데(Shibahara 등, 1995), 본 연구에서는 이 구조물이 아포토시스 소체를 탐식한 정상 과립층세포속에서도 발견되어(Fig. 17, 18), 탐 식성 정상 과립층세포들도 이미 아포토시스 단 계에 들어갔음을 의미하는 것으로 생각된다.

특히 정상과립세포중 일부가 아포토시스 소 체를 탐식하는 것이 관찰(Fig. 17, 18) 되었는 바, 이는 아포토시스에 의해 죽게된 과립세포가 주위에 있는 정상적인 과립세포에 의해서도 탐 식된다는 보고(Koike 등, 1993; Takeo와 Hokano, 1995; Watanabe와 Tonosaki, 1995; Inoue 등, 2000)와 함께, 투명대를 침투해 들어가 퇴화중
인 난자를 탐식하는 것을 발견하였다는 보고 (Inoue 등, 2000) 등과 유사한 소견으로, 이는 일반세포들이 생리적 아포토시스의 과정에서 인접한 정상세포가 아포토시스 소체를 탐식하 는 것과 같은 현상으로 보인다. 그러나 난포내 과립층세포에서 일어나는 이 작용은, 아포토시 스가 불과 $1 \sim 2$ 시간안에 일어나는 이벤트로서 일시적으로 아포토시스 소체가 급격하게 증가 되면 림프구 등 다른 백혈구들의 진입이 불가 피하게 될 것이고 그렇게 되면 난포내에 일시 적 염증상황이 초래되기 때문에(김 등, 2004) 자신이 그들을 일시적으로 탐식하고 자신도 서 서히 아포토시스 단계를 거침으로써, 더 많은 대식세포의 진입과 증식으로 아포토시스 소체 들을 제거할 수 있는 시간 또는 기회를 제공하 

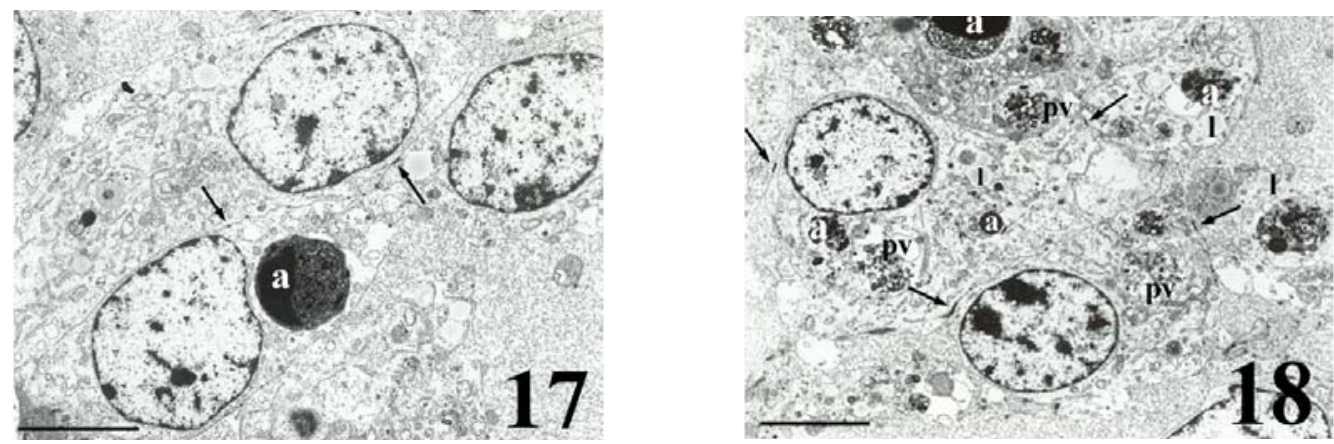

Fig. 17,18. Phagocytosing granulosa cells which contain ingested apoptotic bodies (a), phagocytic vacuoles(v), lipid droplets(I), and having gap junctions(arrow) with neighboring granulosa cells are observed. bar $=5 \mu \mathrm{m}$.

기 위함으로 생각된다. 한편, 아포토시스 소체 를 탐식한 정상 과립층세포들이 자신도 인접세 포와의 연결을 끊고 아포토시스의 길을 가게 되는데, 이것이 어떤 인자에 의해 세포사이 연 결이 끊어지면서 아포토시스의 길을 가게 되는 지 또는 앞서 언급한 바와 같이 이미 프로그램 된 endonuclease의 활성화에 의해 아포토시스가 일어남으로써 세포사이 연결이 끓어지는지는 확실하지 않다. 그러나 과립층세포들의 아포토 시스가 전층에서 무작위로 일어나는 것으로 보 아, 세포밖 기질을 통해 이동되는 어떤 인자들 에 의해 당해 세포에서 아포토시스 프로그램이 개시되고 인접세포와의 연결이 끊어지는 방식 으로 전층에 파급되는 것으로 생각된다. 아울 러 그 인자들은 대식세포에서 분비되는 인자들 일 것(Foghi 등, 1997)으로 추정된다.

한편, 아포토시스 소체들의 제거와 관련하여 지금까지 대식세포에 의한 탐식(Peluso 등, 1980; Garris와 Foreman, 1984; 송, 2003; 김 등, 2004) 되기도 하고, 자가용해(Logothetopoulos 등, 1995), 인접한 정상 과립층세포에 의한 탐 식(Spanel-Borowski, 1981; Kuryszko와 Adamski, 1987; Takeo와 Hokano, 1995; Inoue 등, 2000) 등이 알려져 있으며, 과립층세포들의 아포토시 스 소체들은 주로 주위에 있는 정상적인 세포 들에 의해서 탐식이 일어나고, 대식세포는 퇴 축과정의 후반부에만 작용하고(Kasuya, 1995, 1997; Gáytan 등, 1998), 또한 대식세포의 수가 퇴축중인 난포에서 짧은 시간에 대량으로 고사
되는 과립세포들을 모두 제거하기에는 부족 (Kasuya, 1997) 하다고 하였다. 그러나 본 실험 에서 4E9 단클론항체를 이용하여 아포토시스의 진행에 따른 대식세포의 분포를 살펴본 바, 일 부 난포에서는 과립층에서만 발견되고 일부는 난포동속에서만 발견되고 또 다른 일부는 난포 내 전체에서 발견(Kasuya, 1995)된 것(Fig. 9 11)으로 미루어 생각할 때, 대식세포는 과립층 세포들의 아포토시스 진행과 함께 아포토시스 소체들을 제거하기에 충분한 양이 들어오는 것 으로 생각된다. 그러나 아포토시스의 신속한 진행으로 크게 증가한 아포토시스 소체들을 제 거하기에는 일시적으로 부족한 상태에 빠지게 되어 형태학적으로 자가용해에 의해 소멸되는 것처럼 보이는 것이고, 이를 해결하기 위한 또 하나의 방법으로 인접한 정상 과립층세포들이 아포토시스 소체들을 일시적으로 탐식하는 것 으로 생각된다. 그러나 이도 일시적인 현상이 므로, 아포토시스 소체들의 제거는 궁극적으로 대식세포들에 의한다고 할 수 있겠다. 또한 지 금까지는 정상적인 과립층세포가 퇴화하는 난 모세포를 제거한다고 보고(Inoue 등, 2000)하고 있으나 본 실험에서 대식세포들이 난모세포주 위에 밀집하는 것(Fig. 12)으로 보아 이 또한 대식세포가 제거하는 것으로 보인다.

특히, 본 실험에서 투과전자현미경과 4E9 단 클론항체를 이용한 면역조직학적 연구를 통해 아포토시스를 일으킨 과립세포를 탐식하는 또 다른 세포인 대식세포를 관찰하였는데(Fig. 9 

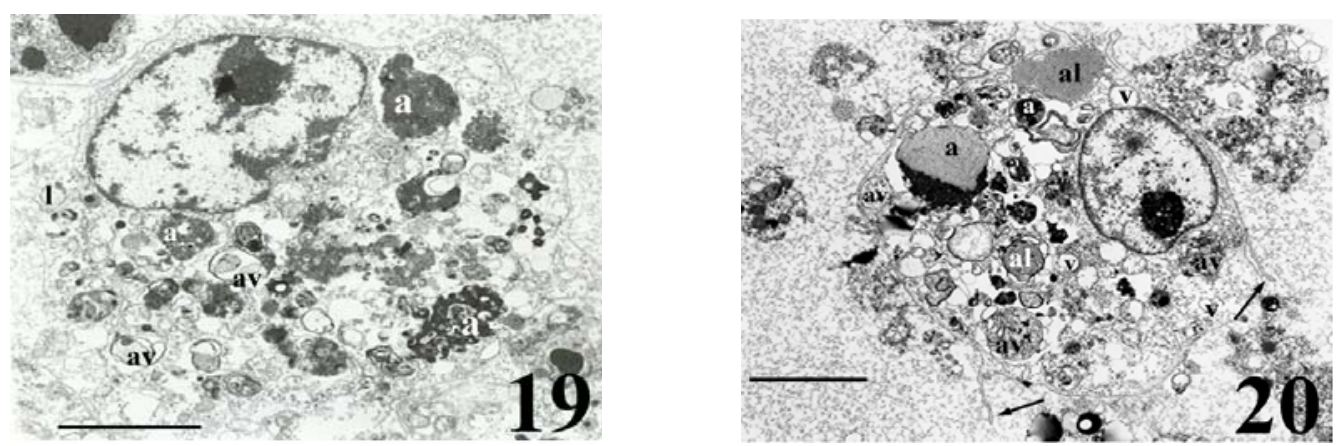

Fig. 19,20. A macrophage in the granulosa cell layer (19) and in the follicular antrum (20) which contain apoptotic bodies(a), autophagic vacuoles(av), autophagolysosomes (al), many vacuoles(v), many lipid droplets $(\mathrm{I})$, and having well defined cytoplasmic processes(arrow) are observed. bar $=5 \mu \mathrm{m}$.

12), 이들은 난포막, 난포과립층 및 난포동에서 모두 관찰되어(Petrovska 등, 1996), 난포동과 과 립세포층에서만 발견된다는 보고(Kasuya, 1995) 들과의 차이를 불식시켰다. 대식세포는 과립층 세포에 비해 핵/세포질 비가 작고 세포질내에 는 아포토시스 소체는 물론 다수의 공포들과 자가포식소체이 있었으며(Fig. 19, 20), 난포동 내에서 발견된 대식세포에서는 특징적으로 긴 세포질돌기들도 관찰되었다(Fig. 20). 지금까지 난소내 대식세포에 대한 연구는 다수 보고되어 있으나, 난포내 대식세포의 출현에 관해서는 보고가 다양하다. 폐쇄를 일으키지 않는 건강 한 난포내 과립층에서도 출현한다는 보고 (Fukumatsu 등, 1992; Bukovsky 등, 1993; Araki 등, 1996), 폐쇄 징후가 없는 성장난포의 과립층 과 난포동에서도 나타난다는 보고(Loukides 등, 1990; Fukumatsu 등, 1992; Bukovsky 등, 1993; Bukovsky 등, 1995), 일차난포를 제외한 모든 난 포와 황체 등에서도 나타난다는 보고(Fukumatsu 등, 1992), 정상난포의 난포막에만 존재하고 난 포 안쪽에는 존재하지 않으며 다만 폐쇄난포에 서만 난포내에 들어가 아포토시스 세포들을 탐 식한다는 보고(Brännström 등, 1993; Petrovska 등, 1996; Hoek 등, 1997)들이 있고, 마우스에서 는 적어도 가임기전(32 35일)에는 관여하는 것 같지 않다는 보고(Inoue 등, 2000)는 등 이견이 있으나, 본 연구에서는 폐쇄가 개시되지 않은 것으로 보이는 정상난포에서는 대식세포 면역
양성반응을 관찰할 수 없었고, 아포토시스가 진행중인 난포에서는 과립층과 난포동 및 난모 세포 주위에서는 물론 난포막에서까지도 면역 반응 양성을 보이고 있어(Fig. 9 12), 대식세포 는 난포내에서 일단 아포토시스가 일어나기 시 작하면 기존에 난포와 난포사이 실질과 난포막 에 위치하고 있던 대식세포들이 활성화되어 난 포내로 진입하고 동시에 난포막 모세혈관으로 부터 대량의 대식세포가 들어오는 것으로 생각 된다. 특히 본 실험에서는 아포토시스에 의해 분절된 농축핵 조각들이 수축된 세포가 쪼개져 생긴 작고 둥근 막성 구조물인 아포토시스소체 속에 갇혀 난포동내에 흩어진 것을 관찰할 수 있었는데(Fig. 21), 이들이 인접한 정상 과립층 세포들(Peluso 등, 1980; Koike 등, 1993; Takeo

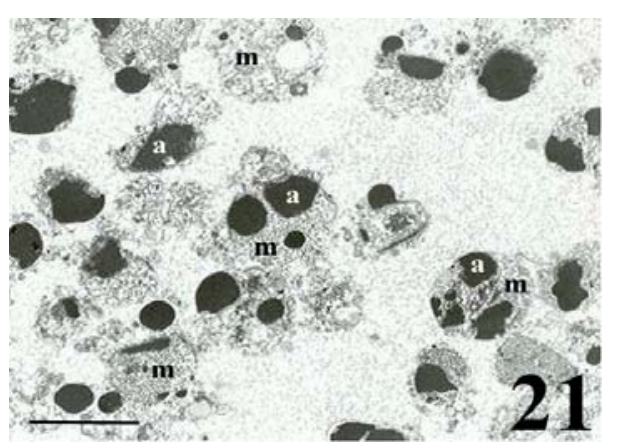

Fig. 21. Many apoptotic bodies (a) within the follicular antrum entrapped by the cytoplasmic processes of macrophages (m) are observed. bar $=5 \mu \mathrm{m}$. 
와 Hokano, 1995; Watanabe와 Tonosaki, 1995; Inoue 등, 2000)이나 대식세포들에 의해(Peluso 등, 1980) 탐식된다는 보고들이 있으나, 분절된 핵조각들을 둘러싸고 있는 전자밀도가 낮은 구 조물은 대식세포 세포질돌기의 세포질(김 등, 2004)로 보이며, 따라서 분절 핵들은 대식세포 에 의해 탐식되는 것으로 생각된다.

대식세포는 잘 알려진 기능인 폐쇄중인 난포 내에서 고사과립세포의 탐식뿐 아니라, 난소의 피질에서는 발달중인 원시난포 주위의 간질에 서 높은 밀도로 나타나 원시난포의 성장개시에 어떤 식으로든지 참여하고 있으며, 아직 확실 하지는 않지만 난포동 난포로 발달한 후에는 난포막세포들이 황체형성호르몬 수용체의 발현 을 조절하여 발육난포를 선택하는 데에도 관여 한다(Petrovska 등, 1996)고 알려져 있다. 난포막 대식세포는 또한 IL-1을 분비하여 미분화 과립 층세포들에서 난포자극호르몬 - 유도 황체형성 호르몬 수용체 발달을 억제하여 난포의 미성숙 황체화를 억제하며(Petrovska 등, 1996) 과립세 포의 성장을 자극(Fukuoka 등, 1989)하는 것으 로 알려져 있다. 이 외에도 대식세포는 GF중의 하나인 PDGF(platelet derived growth factor), FGF, insulin-like GF, TGF $\beta$ 와 TGFa, heparinbinding EGF 등을 분비하는 등 주변분비 및 자 가분비 기전을 통해, 이들 중 특히 FGF와 $\mathrm{EGF}$ 가 과립세포의 성장을 유발(Tapanainen 등, 1987)하여, 과립세포의 증식에 관여(Fukumatsu 등, 1992)하며, 미성숙 흰쥐에서는 난포퇴축을 중개하는 작용(Gáytan 등, 1998)을 갖는다고 한 다. 이와 더불어 대식세포는 그것들이 나타나 는 시기, 위치나 형태에 따라 아형들이 다르고 그에 따른 기능도 다른 점(Dijkstra 등, 1985; Kraal 등, 1988)을 고려할 때, 이 부분에 대해서 는 앞으로 더 연구해야할 것으로 생각한다.

\section{IV 요 약}

난포폐쇄는 과립층세포와 난포막세포들의 아 포토시스에 의해 이루어지고, 이 과정에 대식 세포는 아포토시스 소체들의 포식작용과 각종 사이토카인 분비를 통해 난포폐쇄의 개시와 완
성에 직, 간접적으로 관여함이 널리 보고되어 있다. 그러나 난포 폐쇄시 일어나는 아포토시 스가 어디에서부터 개시되고 어떻게 파급되는 지, 아포토시스 소체의 제거방법, 퇴화된 난모 세포의 제거 방법, 이들을 제거하는 대식세포 의 난포내 진입 시기와 방법 등에 대해서는 아 직 확실히 밝혀져 있지 않다. 이에 저자들은 가임기 돼지(Yorkshire-breed)를 실험동물로 난 소내 난포의 광학현미경적 및 투과전자현미경 적 관찰과 TUNEL 및 돼지 대식세포 단크론항 체 4E9를 이용한 면역조직화학적 방법으로 본 연구를 실시하였다.

본 연구 결과, 난포 폐쇄는 과립층세포의 아포 토시스로부터 개시되고 그 시기에 난포막 속층 세포들의 아포토시스도 같이 일어나는 것으로 관 찰되었다. 과립층세포의 아포토시스는 당해 세포 의 과립층내 위치에 관계없이 핵농축으로부터 시 작되고 짧은 시간안에 과립층 전체로 파급되고 난모세포를 둘러싸고 있는 과립층세포의 아포토 시스가 가장 마지막에 일어나는 것으로 보인다.

난포 과립층세포의 아포토시스는 핵의 농축 과 변형, 세포내 소포들의 츨현이 특징적이었 고, 아포토시스 소체들은 인접한 정상적인 과 립층세포와 대식세포들에 의해 포식되었다. 아 포토시스 소체들을 포식한 정상 과립층세포는 자신도 곧 아포토시스를 일으켜, 이들의 포식 작용은 일시적인 것으로 생각된다. 또한 모든 아포토시스 소체들과 퇴화된 난모세포는 대식 세포들이 제거함을 알 수 있었다.

대식세포는 아포토시스의 개시와 함께 난포 내로 진입하고, 그 진행과 함께 난포내 모든 부위로 이동하여 아포토시스 소체들과 퇴화 난 모세포를 제거하는 것으로 보인다. 처음부터 난포막에 있던 일부 대식세포들은, 아포토시스 를 일으켜 난포 바닥막을 와해시킨 난포막세포 들의 아포토시스 소체들을 제거하여, 폐쇄된 난포의 난소 실질화를 통해 난포 폐쇄의 완성 에 기여하는 것으로 보인다.

$$
\mathrm{V} \text { 사 사 }
$$

본 연구는 한국과학재단 우수연구센터(R11- 
2002-100-00000-0) 지원으로 수행되었으며 이에 감사드립니다.

\section{$\mathrm{VI}$ 인 용 문 헌}

1. Abe, K. and Watanabe, S. 1995. Apoptosis of mouse pancreatic acinar cells after duct ligation. Arch. Histol. Cytol. 58;221-229.

2. Amsterdam, A., Dantes, A., Hosokawa, K., SchereLevy, C. P., Kotsuji, F. and Aharoni, D. 1998. Syeroids adn aging : Steroid regulation during apoptosis of ovarian follicular cells. Steroids, 63: 314-318.

3. Arai, H. 1920. On the postnatal development of the ovary(albino rats), with special reference to the number of ova. Am. J. Anat. 27:405-462.

4. Araki, M., Fukumatsu, Y., Katabuchi, H., Shultz, L. D., Takahashi, K. and Okamura, H. 1996. Follicular development and ovulation in macrophage colony-stimulating factor-deficient mice homozygous for the osteopetrosis mutation. Biol. Reprod. 54: 478-484.

5. Berndt, A., Heller, M., Methner, U., Kosmehl, H. and Mueller, G. 2000. Monoclonal antibodies against porcine macrophages. Vet. Immunol. Immunopathol. 74:163-177.

6. Brännström, M., Mayrhofer, G. and Robertson, S. A. 1993. Localization of leukocyte subsets in the rat ovary during the periovulatory period. Biol. Reprod. 48:277-286.

7. Bukovsky, A., Chen, T. T., Wimalasena, J. and Caudle, M. R. 1993. Cellular localization of luteinizing hormone receptor immunoreactivity in the ovaries of immature, gonadotropin-primed and normal cycling rats. Biol. Reprod. 48:1367-1382.

8. Bukovsky, A., Caudle, M. R., Keenan, A., Wimalasena, J., Foster, J. S. and van Meter S. E. 1995. Quantitative evaluation of the cell cyclerelated retinoblastoma protein and localization of Thy-1 differentiation protein and macrophages during follicular development and atresia, and in human corpora lutea. Biol. Reprod. 52:776-792.

9. Clarke, P. G. H. 1991. Developmental cell death: morphological diversity and multiple mechanisms. Anat. Embryol. 181;195-213.

10. Compton, M. M. and Cidlowski, J. A. 1986. Rapid in vivo effects of glucocorticoids on the integrity of rat lymphocyte genomic deoxyribonucleic acid. Endocrinology, 118:38-45.

11. Cope, F. O. and Willie, J. J. 1991. Carcinogenesis and apoptosis: Paradigms and paradoxes in cell cycle and differentiation. In: Apoptosis: The mo- lecular basis of cell death, Tomei, L. D. and F. O. Cope(ED.), Cold Spring Harbor Laboratory Press, New York, pp. 61-86.

12. Dijkstra, C. D., Döpp, E. A., Joling, P. and Kraal, G. 1985. The heterogeneity of mononuclear phagocytes in lymphoid organs: distinct macrophage subpopulations in the rat recognized by monoclonal antibodies ED1, ED2 and ED3. Immunol. 54:589599.

13. Domenech, N., Rodriquez-Carreno, M. P., Filgueira, P., Alvarez, B., Chamorro, S. and Dominguez, J. 2003. Identification of porcine macrophages with monoclonal antibodies in formalin-fixed, paraffinembedded tissues. Vet. Immunol. Immunopathol. 94: 77-81.

14. Foghi, A., Teerds, K. J., van der Donk, H. and Dorrington, J. 1997. Induction of apoptosis in rat thecal/interstitial cells by transforming growth factor a plus transforming growth factor $\beta$ in vitro. J. Endocrinol. 153:169-178.

15. Fukumatsu, Y., Katabuchi, H., Naito, M., Takeya, M., Takahashi, K. and Okamura, H. 1992. Effect of macrophage on proliferation of granulosa cells in the ovary in rats. J. Reprod. Fert. 96:241-249.

16. Fukuoka, M., Yasuda, K., Taii, S., Takakura, K. and Mori, T. 1989. Interleukin-1 stimulates growth and inhibits progesterone secretion in cultures of porcine granulosa cells. Endocrinology, 124:884-890.

17. Garris, D. R. and Foreman, D. 1984. Follicular growth and atresia during the last half of the luteal phase of the guinea pig estrous cycle : relation to serum progesterone and estradiol levels and uteroovarian blood flow. Endocrinology 115:73-77.

18. Gáytan, F., Morales, C., Bellido, C., Aguilar, E. and Sanchez-Criado, J. E. 1998. Ovarian follicle macrophages: is follicular atresia in the immature rat a macrophage-mediated event? Biol. Reprod. 58(1):52-59.

19. Gougeon, A. 1996. Regulation of ovarian follicular development in primates: facts and hypotheses. Endocrine Rev. 17:121-155.

20. Halme, J., Hammond, M. G., Syrop, C. H. and Talbert, L. M. 1985. Peritoneal macrophages modulate human granulosa-luteal cell progesterone production. J. Clinical Endoclinol. \& Metabol. 61:912916.

21. Han, H., Iwanaga, T., Uchiyama, Y. and Fujita, T. 1993. Aggregation of macrophages in the tips of intestinal villi in guinea pigs: their possible role in the phagocytosis of effete epithelial cells. Cell Tiss. Res. 271;407-419.

22. Hirshfield, A. N. and Midgley, J. A. R. 1978. Morphometric analysis of follicular development in the rat. Biol. Reprod. 19:606-611. 
23. Hoek, A., Allaerts, W., Leenen, P. J. M., Shoemaker, J. and Drexhage, H. A. 1997. Dendritic cells and macrophages in the pituitary and gonads. Evidence for their role in the fine regulation of the reproductive endocrine response. Eur. J. Endocrinol. 136:8-24.

24. Hughes, F. M. and Gorospe, W. C. 1991. Biochemical identification of apoptosis(programmed cell death) in granulosa cells : Evidence for a potential mechanism underlying follicular atresia. Endocrinology, 129(5):2415-2422.

25. Ikeda, K., Kinoshita, H., Hirohashi, K., Kubo, S. and Kaneda, K. 1995. The ultrastructure kinetics and intralobular distribution of apoptotic hepatocytes after portal branch ligation with special reference to their relationship to necrotic hepatocytes. Arch. Histol. Cytol. 58;171-184.

26. Inoue, S., Watanabe, H., Saito, H., Hiroi, M. and Tonosaki, A. 2000. Elimination of atretic follicles from the mouse ovary: a TEM and immunohistochemical study in mice. J. Anat. 196:103-110.

27. Isobe, N. and Yoshimura, Y. 2000. Localization of apoptotic cells in the cystic ovarian follicles of cows: a DNA-end labeling histochemical study. Theriogenology, 53:897-904.

28. Iwanaga, T., Han, H., Adachi, K. and Fujita, T. 1993. A novel mechanism for disposing of effete epithelial cells in the small intestine of guinea pigs. Gastroenterology, 105;1089-1097.

29. Kasuya, K. 1995. The processes of apoptosis in follicular epithelial cells in the rabbit ovary, wit special reference to involvement by macrophages. Arch. Histol. Cytol. 58(2):257-264.

30. Kasuya, K. 1997. Elimination of apoptotic granulosa cells by intact granulosa cells and macrophages in atretic mature follicles of the guinea pig ovary. Arch. Histol. Cytol. 60(2):175-184.

31. Katabuchi, H., Fukumatsu, Y., Araki, M., Suenaga, Y., Ohtake, H. and Okamura, H. 1996. Role of macrophages in ovarian folliclular development. Horm. Res.(Suppl. 1):45-51.

32. Kerr, J. F. R., Searle, J., Harmon, B. V. and Bishop, C. J. 1987. Apoptosis. In Perspectives on Mammalian Cell Death, Potten, C. S.(Ed.), Oxford University Press, Oxford-New York-Tokyo, pp. 93128.

33. Kim, J. K., Lee, C. J., Song, K. W., Do, B. R. and Woon, Y. D. 1999. $\gamma$-Radiation accelerates follicular atresia in immature mice. In Vivo, 13:21-24.

34. Kirsch, T. M., Friedman, A. C., Vogel, R. L. and Flickinger, G. L. 1981. Macropahges in corpora lutea of mice: characterization and effects on steroid secretion. Biol. Reprod. 25:629-638.

35. Koike, K., Watanabe, H., Hiroi, M. and Tonosaki,
A. 1993. Gap junction of stratum granulosum cells of mouse follicles : immunohistochemistry and electron microscopy. J. Electron Microsc. 42:94-106.

36. Kraal, G., Shiamatey-Koolma, R., Hoffer, M., Baker, D. and Scheper, R. 1988. Histochemical identification of guinea-pig macrophages by monoclonal antibody MR-1. Immunology, 65:523-528.

37. Kuryszko, J. and Adamski, R. T. 1987. Macrophages in atretic process of maturing ovarian follicles in mouse. Z. Mikrosc-Anat. Forsch, 101:212220.

38. Lo, A. C., Houenou, L. J. and Oppenheim, R. W. 1995. Apoptosis in the nervous system: Morphological features, methods, pathology, and prevention. Arch. Histol. Cytol. 58;139-149.

39. Lockshin, R. A. and Zakeri, Z. 1991. Programmed cell death and apoptosis. In Apoptosis: The molecular Basis of Cell Death, Tomei, L. D. and Cope, F. O.(Ed.), Cold Spring Harbor Laboratory Press, New York, pp. 47-60.

40. Logothetopoulos, J., Dorrington, J., Bailey, D. and Stratis, M. 1995. Dynamics of follicular growth and atresia of large follicles during the ovarian cycle of the guinea pig : fate of the degenerating follicles, a quantitative study. Anat. Rec. 243:37-48.

41. Loukides, J. A., Loy, R. A., Edwards, R., Honig, J., Visintin, I. and Polan, M. L. 1990. Human follicular fluids contain tissue macrophages. J. Clin. Endocrinol. Metab. 71:1363-1367.

42. Nakamura, M., Yagi, H., Kayaba, S., Ishii, T., Ohtsu, S., Gotoh, T. and Itoh, T. 1995. Most thymocytes die in the absence of DNA fragmentation. Arch. Histol. Cytol. 58;249-256.

43. Nitatori, T., Sato, N., Waguri, S., Karasawa, Y., Araki, H., Shibinai, K., Kominami, E. and Uchiyama, Y. 1995. Delayed neuronal death in the CA1 pyramidal cell layer of the gerbil hippocampus following transient ischemia is apoptosis. J. Neurosci. 15;1001-1011.

44. O'Shea, J. D., Hay, M. F. and Cran, D. G. 1978. Ultrastructural changes in the theca interna during follicular atresia in sheep. J. Reprod. Fertil. 54:183187.

45. Pate, J. L. and Keyes, P. L. 2001. Immune cells in the corpus luteum : friends or foes? Reproduction, 122:665-676.

46. Peluso, J. J., England-Charlesworth, C., Bolender, D. L. and Steger, R. W. 1980. Ultrastructural alterations associated with the initiation of follicular atresia. Cell Tiss. Res. 211:105-115.

47. Petrovska, M., Dimitrov, D. G. and Michael, S. D. 1996. Quantitative changes in macrophage distribution in normal mouse ovary over the course of the estrous cycle examined with an image analysis 
system. A. J. R. I. 36;175-183.

48. Schulte-Hermann, R., Bursch, W., Kraupp-Grasl, B., Oberhammer, F. and Wagner, A. 1992. 1992 Programmed cell death and its protective role with particular reference to apoptosis. Toxicol. Lett. 6465 (Spec. No.):569-574.

49. Shibahara, T., Sato, N., Waguri, S., Iwanaga, T., Nakahara, A., Fukutomi, H. and Uchiyama, Y. 1995. The fate of effete epithelial cells at the villus tips of the human small intestine. Arch. Histol. Cytol. 58;205-219.

50. Singh, N. and Anand, S. 1995. Apoptosis in health and disease. Indian J. Physiol. Pharmacol. 39(2): 91-94.

51. Spanel-Borowski, K. 1981. Morphological investigations on follicular atresia in canine ovaries. Cell Tiss. Res. 214:155-168.

52. Suzuki, K., Izumi, T., Iwanaga, T., Fujita, T. and Shibata, A. 1995. Multinucleated giant cells undergoing apoptosis in experimental autoimmune myocarditis. Arch. Histol. Cytol. 58;231-241.

53. Takashita, N., Homma, S., Rotello, R. J., Fernandez, P. A., Yuan, J., Oppenheim, R. W. and Yaginuma, H. 1995. Expression of apogens and engulfens during programmed cell death in the nervous system of the chick embryo. Arch. Hisol. Cytol. 58;243-248.

54. Takeo, Y. and Hokano, M. 1995. An electron microscopic study of apoptosis in the granulosa layer of ovarian follicles in rats treated with continuous illumination. Med. Electron. Microsc. 28:38-44.

55. Taniguchi, K., Sato, N. and Uchiyama, Y. 1995. Apoptosis and heterophagy of medial edge epithelial cells of the secondary palatine shelves during fusion. Arch. Histol. Cytol. 58;191-203.

56. Tapanainen, J., Yamamoto, M., Leinonen, P. J., Jaffe, R. B. and Tapanainen, P. 1987. Regulation of human granulosa-luteal cell progesterone production and proliferation by gonadotropins and growth factors. Fertil. Steril. 48:576-580.

57. Terranova, P. F. 1981. Steroidogenesis in experimentally induced atretic follicles of the hamster : a shift from estradiol to progesterone synthesis. Endocrinology, 108:1885-1890.
58. Tilly, J. L., Kowalski, K. I., Johnson, A. L. and Hsueh, A. J. W. 1991. Involvement of apoptosis in ovarian follicular atresia and postovulatory regression. Endocrinology. 129:2799-2801.

59. Tsafriri, A. and Braw, R. H. 1984. Experimental approaches to atresia in mammals. Oxf. Rev. Reprod. Biol. 6:226-265.

60. Ueda, N. and Shah, S. V. 1994. Apoptosis. J. Lab. Clin. Med. 124:169-177.

61. Uilenbroek, J. T. L., Woutersen, P. J. A. and van der Schoot, P. 1980. Atresia of preovulatory follicles : gonadotropin-binding and steroidogenic activity. Biol. Reprod. 23:219-229.

62. Watanabe, H. and Tonosaki, A. 1995. Gap junction in the apoptosis : TEM observation of membrana granulosa cells of mouse ovarian follicle. Prog. Cell. Res. 4:37-40.

63. Wyllie, A. H. 1980. Glucocorticoid-induced thymocyte apoptosis is associated with endogenous endonuclease activation. Nature, 284:555-556.

64. Wyllie, A. H., Kerr, J. F. R., Macaskill, I. A. M. and Currie, A. R. 1973a. Adrenocortical cell deletion: the role of ACTH. J. Pathol. 111;85-94.

65. Wyllie, A. H., Kerr, J. F. R. and Currie, A. R. 1973b. Cell death in the normal neonatal rat adrenal cortex. J. Pathol. 111;255-261.

66. Zeleznik, A. J., Ihrig, L. L. and Bassett, S. G. 1989. Developmental expression of $\mathrm{Ca}^{++} / \mathrm{Mg}^{++}$ dependent endonuclease activity in rat granulosa and luteal cells. Endocrinology, 125:2218-2220.

67. 김수일, 한승로, 조근자, 허대영, 이영호, 조문준, 김무강, 김원식. 2002. 방사선 조사에 의한 흰쥐 난포의 퇴축과 난포 세포의 방사선 감수성. 충남 의대잡지. 29(1):1-17.

68. 김원식, 한승로, 김수일, 박창식. 2004. 돼지난소 에서 난포 폐쇄와 대식세포에 관한 형태학적 연 구. 대한해부학회지 37(1);9-18.

69. 송근일. 2003. 방사선에 의한 난포 퇴축과 난포 macrophage에 관한 형태학적 연구. 충남대학교 박사학위논문.

(접수일자 : 2004. 4. 21. / 채택일자 : 2004. 6. 9.) 